\title{
Performance Analysis of Zakat Practices in Pati Regency (Case Study: The National Board of Zakat [BAZNAS] Pati Regency, Indonesia)
}

Fitriani

Bogor Agricultural University

\begin{abstract}
A crucial problem faced by Indonesia is its high poverty rate. One of the redistribution instruments that can be used to reduce poverty is zakat. The zakat potential of Pati Regency, Indonesia in 2016 was approximately Rp 20 billion, but the funds collected only amounted to around 9 percent of this figure ( $R p 1.8$ billion). This statistic shows that the management of zakat is not optimized, both in terms of its collection and distribution. This study aims to evaluate the performance of zakat practices, and the influence of zakat on the welfare of mustahik (recipients of zakat) in Pati Regency, Indonesia. The research was conducted by means of a survey of 100 households of mustahik and interviews. The sampling method that used in this research was purposive sampling technique. Analysis of the result was undertaken using by National Zakat Index (NZI) and Muti-Stage Weight Index Method. The result of this research show that the performance of zakat practices in Pati Regency is in the "less good" category with an index value of 0.392.
\end{abstract}

Keywords: Poverty, National Zakat Index, Performance of Zakat Practices

\section{INTRODUCTION}

The poverty rate in Pati Regency, Indonesia is quite high. Based on BPS data, in 2015 in Pati Regency, 147,100 people or about 11.95 percent of its populations were poor. One of the instruments that can be used to reduce poverty is zakat. In the figh contex zakat is defined as a certain amount of wealth that Allah requires the owner to hand over to those who are entitled to receive it (Qardawi, 2011). In addition, zakat not only serves to help the mustahik (recipient of zakat) economy, but also becomes a counterweight instrument in the national economic sector. In the long run, the main purpose of zakat is to transform the mustahik into muzakki, those who pay zakat (Beik, 2009).

The National Board of Zakat (BAZNAS) Pati Regency is one of the official zakat management organization in
Pati Regency. In 2016, BAZNAS Pati Regency managed to raise funds amounting to Rp 1.8 billion. However, the amount is equivalent to only 9 percent of the zakat potential of the Pati Regency. According to Kaprodi Management Zakat dan Wakaf Institut Pesantren Mathali'ul Falah (IPMAFA), Dr. Jamal Ma'mur Asmani, who is also the vice chairman PCNU Pati, the zakat potential of Pati Regency is around $\mathrm{Rp} 20$ billion. This estimation is based on BPS data from 2015, which showed that the population of Pati Regency amounted to 1,232,912 people, with a Muslim population of $1,200,656$ people or about 97 percent. It is evident that there is a gap between the zakat funds that have accumulated and the zakat potensial. This indicated that the management of zakat is not yet optimal, in terms of both the collection and distribution of zakat. In order to measure the zakat performance in this region, an 
indicator is needed. The zakat performance indicator used in this study is the National Zakat Index (NZI). Thus, this research aims to assess and evaluate the performance of zakat practices in Pati Regency by using the NZI.

\section{LITERATURE REVIEW}

Shabri (2011) conducted a study with the aim of evaluating the performance of Regional Amil Zakat Agency (BAZDA) and Amil Zakat Institution (LAZ) in West Sumatera Province, with regard to the managing of zakat funds, based on 2010 data. The study employed the prime performance measurement method proposed in the Indonesian Zakat and Development Report (IZDR) 2011, which includes five components of measurement, namely: 1) Sharia compliance performance, legality and institution, 2) management performance, 3) financial performance, 4) economic empowerment performance, and 5) social legitimacy performance. The performance of these two institutions were then compared and the significance of the difference was measured using $U$ test or Mann Whitney $U$ test. The test result indicated a significant difference between the performance of BAZDA and LAZ in West Sumatra Province in managing zakat. BAZDA's performance was found to be better than that of LAZ, especially in terms of financial performance and performance of sharia legitimacy.

Saf (2015) analyzed the effectiveness of the implementation of zakat management regulation in Mojokerto and Sidoarjo Regency, with the aims of improving the welfare of communities in those area. The study employed the theory of legal effectiveness approach. The results showed that the management of zakat by the Board of Zakat in both Mojokerto and Sidoarjo Regency became more effective when the zakat management regulations were implemented. This was exemplified by the increase in the number of muzakki, in the zakat funds collected and in the Board of Zakat operational costs charged to APBD.

Nasrullah (2015) analyzed zakat regulation and productive zakat application in a case study at Baitul Mal North Aceh Regency. This study aims to support community empowerment and the prosperity of society. The method used was descriptive analysis. The results show that Baitul Mal North Aceh Regency is bound by a number of regulations. Productive zakat is implemented to provide business capital loans based on qard al-hasan and there by motivate business as much as possible. This program has a significant impact in supporting the prosperity of the people.

Murniati and Beik (2013) analyzed the effect of zakat on Human Development Index (HDI) and on the level of poverty among mustahik in their case study of the empowerment of BAZNAS Bogor City. This study aimed to analyze the utilization of the zakat program conducted by BAZNAS Bogor City and its impact on the lives of mustahik, both in terms of changes in the income mustahik post zakat distribution, and of HDI value and poverty level of mustahik. Through the use $\mathrm{t}$ statistical calculation method, an individual level of HDI, and a poverty indicator, it was concluded that zakat play a positive role in improving the development mustahik in Bogor City.

Using the CIBEST model Pratama (2015) examined the utilization of productive zakat in reducing poverty (case study: PT Masyarakat Mandiri Dompet Dhuafa). More specifically, this study aimed to analyze the impact of productive zakat in reducing the poverty of mustahik households by observing conditions before and after productive zakat funds were received. The results showed that there was an increase in the average household income after receiving the aid of productive zakat funds. 
Abdullah, Yusop, and Awang (2012) created an indicator of zakat effectiveness, which measures the extent to which the government's role of allocation the budget impacts on the success of zakat. Using different dimensions, Noor, Rasool, Ali, and Rahman (2015) measured the institutional aspect of the performance of zakat using the zakat index. The zakat index evaluates the overall performance of a zakat institution with respect to: input, process, output, and outcames. The results show that the assistance provided by the two zakat institutions concerned can improve the quality of life for the beneficiary or mustahik.

According to Hafidhuddin (2002), zakat is beneficial for muzakki, mustahik the assets subject to zakat. The wisdom and benefits of zakat are as follows: 1) The manifestation of faith in Allah SWT, grateful for His favors, cultivate noble morals with a strong sense of humanity, eliminates miserliness, greed and materialism, fosters the tranquility of life, and develops property owned. 2) Zakat is a right mustahik, which serves to help and nurture them, especially enabling the poor to meet their needs, improve the quality of their lives, and avoid kufr. 3) As a pillar of mutual charity (jama'i) between the rich and the mujahid, who always strive in the cause of Allah, zakat constitutes a form of social security in Islam. 4) Zakat socializes the appropriate business ethics for those involved in obtaining property in accordance with the provisions of Allah SWT. 5) Zakat enables the distribution of income, so treasures are not restricted to certain groups. Proper management of zakat can increase economic growth.

\section{RESEARCH METHODOLOGY}

Data

This research uses two sources of data: primary and secondary data. Primary data is acquired through questionnaires and interviews, both of which survey the mustahik of BAZNAS Pati Regency. On the other hand, secondary data is obtained througha literature study such as books, journals, articles and relevant documents from the Central Bureau of Statistics, BAZNAS Pati Regency.

This research applies a purposive sampling technique in which the respondents are chosen according to selected characteristics. The sample consists of 100 households of mustahik who received zakat from BAZNAS Pati Regency in 2016. The mustahik come from five village, namely Tegal Ombo, Kembang, Gadudero, Pakem, Kuwawur.

\section{Data Analysis Methods}

\section{a. National Zakat Index (NZI) Analysis}

The NZI that was a measuring instrument developed with the aim of evaluating the development of aggregate conditions at the aggregate level (national and provincial). NZI consists of two dimensions: macro dimension and micro dimension. The macro dimension reflects the role of government and society in aggregate, in contributing to the building of zakat institutions. This dimension has three indicators: regulation, government budget allocation (APBN), and the zakat institution database. The zakat institution database indicator is futher divided into three variables: the number of official zakat institutions,individual muzakki ratio, and the corporate muzakki ratio. 


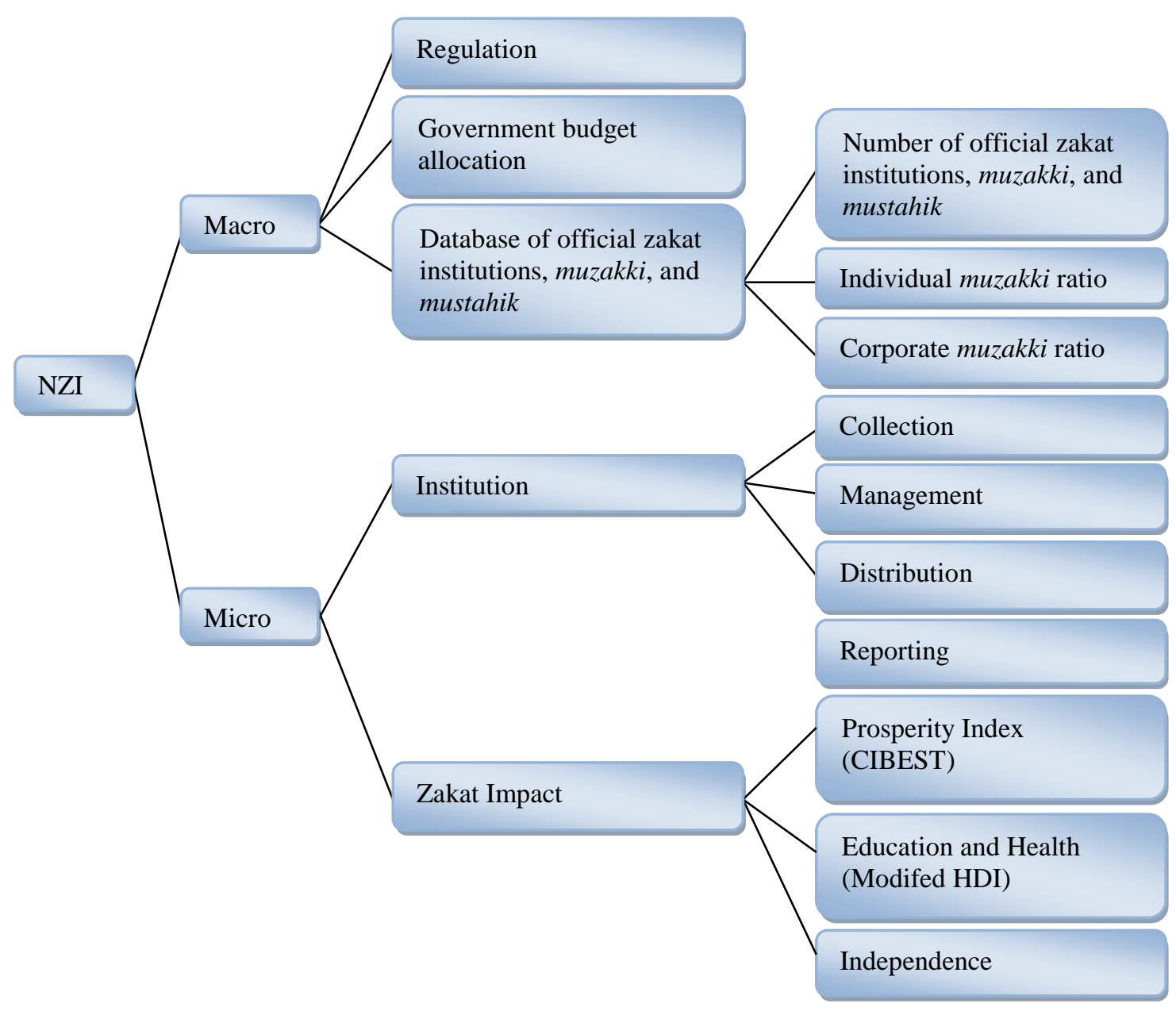

Figure 1. NZI Component

The micro dimension reflects the institutional aspect of zakat and the beneficiaries of zakat. This dimension consists of two indicators namely: the institutional indicator and the zakat impact indicator. The institutional indicator consists of four variables: collection, management, distribution, and reporting of zakat.
Meanwhile, the zakat impact indicator consists of three variables, namely: CIBEST prosperity index, modified HDI, and independence (Puskas BAZNAS 2016). Figure 1 provides an overview of the NZI constituent components, while the weighted score for each component can be observed in the Table 1. 
Table 1. Weighted Score of NZI Components

\begin{tabular}{|c|c|c|c|c|c|}
\hline Dimension & $\begin{array}{c}\text { Weighted } \\
\text { score }\end{array}$ & Indicator & $\begin{array}{l}\text { Weighted } \\
\text { score }\end{array}$ & Variable & $\begin{array}{l}\text { Weighted } \\
\text { score }\end{array}$ \\
\hline \multirow[t]{5}{*}{$\begin{array}{c}\text { Macro } \\
\left(X_{1}\right)\end{array}$} & \multirow[t]{5}{*}{0.40} & $\begin{array}{l}\text { Regulation } \\
\left(X_{11}\right)\end{array}$ & 0.30 & Re gulation & 1.00 \\
\hline & & $\begin{array}{l}\text { Government } \\
\text { Budget } \\
\text { Allocation }\left(X_{12}\right)\end{array}$ & 0.40 & $\begin{array}{l}\text { Government } \\
\text { Budget Allocation }\end{array}$ & 1.00 \\
\hline & & \multirow[t]{3}{*}{$\begin{array}{l}\text { Zakat Institution } \\
\text { Database }\left(X_{13}\right)\end{array}$} & \multirow[t]{3}{*}{0.30} & $\begin{array}{l}\text { Number of } \\
\text { Official Zakat } \\
\text { Institution }\left(X_{131}\right)\end{array}$ & 0.33 \\
\hline & & & & $\begin{array}{l}\text { Individual } \\
\text { Muzakki Ratio } \\
\left(X_{132}\right)\end{array}$ & 0.33 \\
\hline & & & & $\begin{array}{l}\text { Corporate } \\
\text { Muzakki Ratio } \\
\left(X_{133}\right)\end{array}$ & 0.33 \\
\hline \multirow[t]{7}{*}{$\operatorname{Micro}\left(X_{2}\right)$} & \multirow[t]{7}{*}{0.60} & \multirow{4}{*}{$\begin{array}{l}\text { Institutional } \\
\left(X_{21}\right)\end{array}$} & \multirow[t]{4}{*}{0.40} & Collection $\left(X_{211}\right)$ & 0.30 \\
\hline & & & & $\begin{array}{l}\text { Management } \\
\left(X_{212}\right)\end{array}$ & 0.20 \\
\hline & & & & $\begin{array}{l}\text { Distribution } \\
\left(X_{213}\right)\end{array}$ & 0.30 \\
\hline & & & & Reporting $\left(X_{214}\right)$ & 0.20 \\
\hline & & \multirow[t]{3}{*}{$\begin{array}{l}\text { Impact of Zakat } \\
\left(X_{22}\right)\end{array}$} & \multirow[t]{3}{*}{0.60} & $\begin{array}{l}\text { Prosperity Index } \\
(\text { CIBEST })\left(X_{221}\right)\end{array}$ & 0.40 \\
\hline & & & & $\begin{array}{l}\text { Education and } \\
\text { Health (HDI } \\
\text { Modified) }\left(X_{222}\right)\end{array}$ & 0.40 \\
\hline & & & & $\begin{array}{l}\text { Independence } \\
\left(X_{223}\right)\end{array}$ & 0.20 \\
\hline
\end{tabular}

Source: Center of Strategic BAZNAS (2017)

The NZI formulation model is divided systematically into five step. The first step involves creating the likert scale with a range from 1 to 5 , where a score of 1 represents the worst performance, and the score of 5 represents the excellent performance. In the second step, the index of each variable is calculated. The formula for calculation the index on each variable is as follows:

$$
I_{i}=\frac{\left(S_{i}-S_{\min }\right)}{\left(S_{\max }-S_{\min }\right)}
$$

where

$I_{i} \quad$ : index of variabel $i$

$S_{i} \quad$ : value of the actual score of variabel $i$

$S_{\max }:$ maximum score
$S_{\min }:$ minimum score

The index value lies within the range of 0.00 to 1.00 . This means the a low index value indicates the poor performance of the national zakat, and a high index value indicates a better national zakat performance. The NZI index scores are divided into five categories, namely: "not good" (0.00 to 0.20$)$, "less good" (0.21 to 0.40$)$, "fairly good" (0.41 to 0.60$)$, "good" (0.61 to 0.80$)$, and "very good" (0.81 to 1.00$)$.

The third step is to multiply the index obtained for each variable by itsrespective weight in order to derive the index of the indicators. Two of the indicators, regulation and government budget allocation are not divided into more detailed variables, and so further 
calculations are not required to derive their indices. Meanwhile, the indices of remaining three indicators, which are divided into several variables are calculated with the following formula:

$X_{13}=0.33 X_{131}+0.33 X_{132}+0.33 X_{133}$

where

$X_{13}$ : Indicator index of zakat institution database

$X_{131}$ : Variable index of total number of official zakat institutions, registered muzakki and mustahik

$X_{132}$ : Variable index of individual muzakki ratio against the total number of households

$X_{133}$ : Variable index of corporate muzakki ratio against the total number of enterprises

$X_{21}=0.30 X_{211}+0.20 X_{212}+0.30 X_{213}+$ $0.20 X_{214}$

where

$X_{21} \quad$ : Institution indicator index

$X_{211}$ : Variable index of collection

$X_{212}$ : Variable index of management

$X_{213}$ : Variable index of distribution

$X_{214}$ : Variable index of reporting

$X_{22}=0.40 X_{221}+0.40 X_{222}+0.20 X_{223}$

where

$X_{22}$ : Indicator index of zakat impact

$X_{221}$ : Variable index of prosperty index (based on CIBEST Model)

$X_{222}$ : Variable index of eduation and health (Modified HDI)

$X_{223}$ : Variable index of independence

The fourth step involves multiplying the index obtained for each indicator by its respective weight in order to obtain the index of the macro and micro dimensions. The formulae used are as follows:
$X_{1}=0.30 X_{11}+0.40 X_{12}+0.30 X_{13}$

where

$X_{1} \quad$ : Index of macro dimension

$X_{11}$ : Indicator index of regulation

$X_{12}$ : Indicator index of government budget allocation

$X_{13}$ : Indicator index of zakat institutions database

$$
X_{2}=0.40 X_{21}+0.60 X_{22}
$$

where

$X_{2} \quad$ : Index of micro dimension

$X_{21} \quad$ : Institutional indicator index

$X_{22}$ : Indicator index of zakat impact

In the final step, the index obtained for each dimension is multiplied by its respective weight in order to obtain the NZI using the following formula:

$$
\mathrm{NZI}=0.40 X_{1}+0.60 X_{2}
$$

where

NZI : National Zakat Index

$X_{1} \quad$ : Index of macro dimension

$X_{2} \quad$ : Index of micro dimension

\section{b. CIBEST Analysis}

The CIBEST model was developed by Beik and Arsyianti (2015) and consists of four quadrants which represent human's basic needs, both material and spiritual. The quadrant are divided according to the ability of the household to meet these material and spiritual needs. In the first quadrant, households are able to meet both material and spiritual needs. This is the welfare quadrant. In the second quadrant, households are capable of fulfilling spiritual needs but are unable to properly meet material needs. This is the material poverty quadrant. In contrast, in the third quadrant, households are able to meet material needs but are unable to fulfil spiritual needs. This is the spiritual poverty quadrant. In the fourth quadrant, 
households are unable to meet both material and spiritual needs. This is the absolute poverty quadrant. The CIBEST model calculates the number of people residing in each quadrant and therefore has implications for government policy. The focus needs to be calculated is the material and spiritual needs. The unit of analysis of the CIBEST model is the household or the family. The CIBEST model consists of four indexes: welfare index, material poverty index, spiritual poverty index, and absolute poverty index.

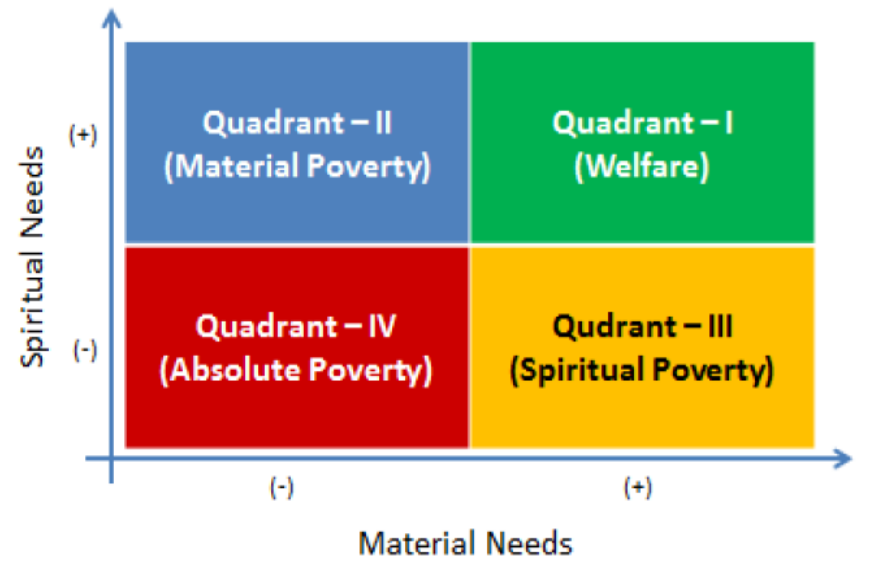

Source: Beik and Arsyianti (2015)

Figure 2. CIBEST Model

\section{RESULT AND ANALYSIS}

The NZI measurement consists of two dimensions: the macro and the micro dimensions. In the macro dimension, Pati Regency has an index value of 0.05 . This means that the performance of zakat practices in Pati Regency is in the "not good" category. This dimension consist of three indicators namely: regulation, local government budget allocation to BAZNAS Pati Regency, and database of zakat institutions in Pati Regency.

Pati Regency did not have a local regulation regarding zakat. Thus, the regulation indicator Pati Regency has an index score of 0 . Moreover, this region also did not allocate any of its local government budget to the operational cost of zakat activities. So, the government budget allocation indicator also has an index score of 0 .

On the other hand, the zakat institution database indicator contists of three variables, namely: (1) the number of official zakat institutions, muzakki, and mustahik, (2) ratio of individual muzakki, and (3) ratio of corporate muzakki. Pati Regency already has zakat institutions and the mustahik who had been registered to each institutions, so that the index score for this variable is 0.5 . For the ratio of individual muzakki to the total number households, the index score is 0 . This is due to a very low proportion of muzakki in the region (less than one percent, only 32 muzakki out of 424,616 households). The ratio of corporate muzakki to the total number of companies also has an index score of 0 , as none of the 531 companies in Pati Regency were registered as corporate muzakki.

When these three variables are combined, the zakat institution database indicator has a score of 0.165 , meaning that the performance of zakat practices in Pati Regency is in the "not good" category. However, this indicator has the hightest score of the indicators in the macro dimension. Details of the macro dimension score are illustrated in the Table 2. 
Table 2. Macro Dimension Index Score

\begin{tabular}{|c|l|c|}
\hline No & \multicolumn{1}{|c|}{ Indicator } & Index Score \\
\hline 1 & Regulation $\left(X_{11}\right)$ & 0 \\
\hline 2 & Local government budget allocation $\left(X_{12}\right)$ & 0 \\
\hline 3 & Database of zakat institutions in Pati Regency $\left(X_{13}\right)$ & 0.165 \\
\hline \multicolumn{2}{|l|}{ Index score of macro dimension in Pati Regency } \\
$=0.30\left(X_{11}\right)+0.40\left(X_{12}\right)+0.30\left(X_{13}\right)$ \\
$=0.30(0)+040(0)+0.30(0.165)$ \\
$=0.05$ \\
\\
Source: Primary data $(2017)$ \\
\hline
\end{tabular}

Source: Primary data (2017)

The second dimension is the micro dimension which consists of two indicators: the institutional indicator and the zakat impact indicator. The institutional indicator is related to the performance of BAZNAS Pati Regency in managing zakat and is divided into four variables, namely: zakat collection, management, distribution, and reporting. Meanwhile, the zakat impact indicator is associated with the impact and benefit of zakat for mustahik as zakat receivers. The zakat impact indicator consists of three variables, namely: prosperity index (CIBEST model), education and health (modified HDI), and independence.

For the institutional indicator, the zakat collection variable is measured by the growth of the zakat fund collection by the BAZNAS Pati Regency. The zakat collection incrased by 88 percent in 2016 (from $\mathrm{Rp} 968,992,481$ in 2015 to $\mathrm{Rp}$ $1,821,746,595$ in 2016). This variable has an index score of 1, meaning that the zakat collection BAZNAS Pati Regency is classified as "very good". The zakat management variable is indicated by the existence of Standard Operation Procedure (SOP), strategic plan, annual zakat program, and ISO certification or quality assurance. BAZNAS Pati Regency already has a SOP, strategic plan, and annual zakat program, so this variable has an index score of 0.75 . This means that the zakat management of BAZNAS Pati Regency is in the "good" category.

In terms of the zakat distribution variable, BAZNAS Pati Regency has an Allocation to Collection Ratio of 19.42 percent. This means that the zakat fund had not been optimally distributed in 2016 . This variable has an index score of 0.5 and so is in the "fairly good" category. However, the zakat reporting variable has an index score of 0.25 , meaning that it is in the "less good" category. This is because BAZNAS Pati Regency's financial report had not been audited externally. Well all its variables are combined, the institutional indicator is in the "fairly good" category, with index value 0.65 , which means that BAZNAS Pati Regency has a quite good institutional performance.

For the zakat impact indicator, the prosperity index (CIBEST model) has an index score of 0.75 . This mean that in terms of mustahik welfare, the zakat performance in Pati Regency is in the "good" category. Meanwhile, the education and health variable, using a modified HDI, has an index score of 0.5. This index measures the life viability of mustahik, based on their life expectancy assessment and level of education. The index score of this variable indicates that the education and health condition of mustahik in Pati Regency is in the "fairly good" category. The independence variable is found to have the same index score of 0.5 . The independence level of mustahik is measured according to their occupation or business, and their saving. The index score of this variable indicates that the occupation and savings of the mustahik in Pati Regency are in the "fairly good" category. When these three variables are combined, the zakat impact indicator is found to have an index score 
0.60. This means that zakat impact on mustahik in Pati Regency is in the "fairly good" category.

Overall, the micro dimension has an index value of 0.62 . This shows that, in the micro dimension, the performance of zakat practices in Pati Regency, especially in BAZNAS Pati Regency is classified as "quite good". The details of the micro dimension index score are presented in Table 3.

Table 3. Micro Dimension Index Score

\begin{tabular}{|c|l|c|}
\hline No & \multicolumn{1}{|c|}{ Indicator } & Index Score \\
\hline 1 & Institutional $\left(X_{21}\right)$ & 0.65 \\
\hline 2 & Zakat Impact $\left(X_{22}\right)$ & 0.60 \\
\hline \multicolumn{2}{|l|}{ Index score of micro dimension in Pati Regency } \\
$=0.40\left(X_{21}\right)+0.60\left(X_{22}\right)$ & \\
$=0.40(0.65)+0.60(0.60)$ & \\
$=0.62$ & \\
\hline
\end{tabular}

Source: Primary data (2017)

Based on the calculation of the index scores of the macro and micro dimensions, the NZI value of Pati Regency is found to be 0.392, meaning that the performance of zakat practices in Pati Regency is categorized as "less good". Details of the NZI results can be observed in the Table 4.

Table 4. National Zakat Index (NZI) in Pati Regency

\begin{tabular}{|c|l|c|}
\hline No & \multicolumn{1}{|c|}{ Dimension } & Index Score \\
\hline 1 & Macro & 0.05 \\
\hline 2 & Micro & 0.62 \\
\hline \multicolumn{2}{|c|}{ NZI score in Pati Regency $=0.40(0.05)+0.60(0.62)=0.392$} \\
\hline
\end{tabular}

Source: Primary data (2017)

\section{CONCLUSION AND RECOMMENDATION}

The result of the NZI calculation showed that the overall zakat performance in Pati Regency is in the "less good" category with index value of 0.392 . In the macro dimension, the zakat performance in Pati Regency is in the "not good" category with an index value of 0.05 . Maenwhile, in the micro dimension, the zakat performance in Pati Regency, especially that of BAZNAS Pati Regency, is in the "fairly good" category, with index value of 0.62 .

Several steps which can be carried out to improve the performance of zakat practice in Pati Regency, such as initiating a local government budget to support zakat and formulating local regulations for zakat. In addition, it is important to improve the monitoring and reporting aspects of zakat management in order to build people's trust to zakat institutions, and there by incrase the zakat collection funds (Zaenal, Choirin, Tsabita, Astuti, \& Sadariyah, 2017 as cited in Diana, Beik, \& Tsabita, 2017).

\section{REFERENCES}

Abdullah, N., Yusop, M.M.M., \& Awang, C.O. (2012). A technical note on the derivation of Zakat Effectiveness Index. International Journal of Economics, Management and Accounting, 20 (1), 75-86. 
BAZNAS Center of Strategic Studies. (2016a). Indonesia zakat outlook 2017. Retrieved from http://puskasbaznas.com/outlook/in donesia-zakat-outlook-2017/69outlook-zakat-indonesia-2017english.

BAZNAS Center of Strategic Studies. (2016b). National Zakat Index. Retrieved from http://puskasbaznas.com/nationalzakat-index/nzi/download/72-nzi-2.

Beik, I.S. (2009). Analysis of the role of zakat in alleviating poverty. Jurnal pemikiran dan gagasan, 2.

Beik, I.S., \& Arsyianti, L.D. (2015). Construction of CIBEST model as measurement of poverty and welfare indices from Islamic perspectives. Al-Iqtishad, 7(1), 87104.

Central Bureau of Statistics (2016). Statistics of Indonesia 2016. Jakarta (ID): BPS.

Central Bureau of Statistics (2016). Pati Regency in Numbers 2016. Pati Regency (ID): BPS Kota Pati.

Diana, Beik, I.S., \& Tsabita, K. (2017). Performance analysis of zakat practices in East Lampung Regency using National Zakat Index (NZI). (Puskas Baznas Working Paper Series [PWPS]).

Firdaus, M., Beik, I.S., Irawan, T., \& Juanda, B. (2012). Economic estimation and determinations of zakat potential in Indonesia. (Islamic Research and Training Institute [IRTI] Working Paper Series: W\# 1433-07). Jeddah.

Hafidhuddin, D. (2002). Zakat in the modern economy. Jakarta (ID): Gema Insani Press.

Murniati, R., \& Beik, I.S. (2013). Influence of zakat against Human Development Index and poverty level mustahik: Case studies utilization BAZNAS Bogor City. Journal of Al-Muzara'ah. 2 (2), 131-145.
Nasrullah. (2015). Zakat regulation and zakat productive implementation as support for community empowerment. Journal of Religious Social Research, 9 (1), 124.

Noor, A.H.M., Rasool, M.S.A., Ali, R.M.Y.S.M, \& Rahman, R.A. (2015). Efficiency of Islamic institutions: Empirical evidence of zakat organizations performance in Malaysia. Journal of Economics, Business and Management, 3 (2), 282-286.

Pratama C. 2015. Effective use of zakat in reducing poverty based on CIBEST Model (Case study: PT Masyarakat Mandiri Dompet Dhuafa) (thesis). Bogor (ID): Bogor Agricultural University.

Qardawi, Y. (2011). Hukum Zakat. Jakarta: Litera Antarnusa.

Saf, M.A. (2015). Effectiveness of implementation of zakat management regulation in Mojokerto and Sidoarjo. Journal of Islamic Laws and Law, 5 (2), 313332.

Shabri, H. (2011). Performance Measurement of Amil Zakat and Amil Zakat Institution in West Sumatera Province (thesis). Jakarta (ID): University of Indonesia.

Zaenal, M., Choirin, M., Tsabita, K., Astuti, A., \& Sadariyah, A. (2017). Principles of Amil Zakat and best practice recommendations for Zakat Institutions. Puskas Baznas Working Paper Series (PWPS). Retrieved from http://puskasbaznas.com/publicatio n/index.php/workingpaper/article/v iew/19.

Fitriani

Bogor Agricultural University

Indonesia

anifitri929@gmail.com 